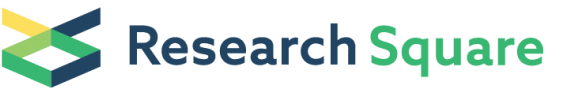 \\ Preprints are preliminary reports that have not undergone peer review. \\ They should not be considered conclusive, used to inform clinical practice, or referenced by the media as validated information.
}

\section{Community Health Worker Knowledge, Attitudes, and Practices Towards Epilepsy in Mozambique}

Vasco Francisco Japissane Cumbe ( $\sim$ vcumbe@gmail.com )

Beira Central Hospital - Service Psychiatry https://orcid.org/0000-0002-1131-8597

\section{Claire Greene}

New York State Psychiatric Institute

\section{Afonso Mazine Tiago Fumo}

Medicine Department, Service of Psychiatry, Beira Central Hospital

\section{Hélder Fumo}

Mental Health Department, Ministry of Health, Provincial Health Directorate of Sofala

\section{Dirceu Mabunda}

Mental Health and Psychiatry Department, Faculty of Medicine, Eduardo Mondlane University

\section{Maria Lídia Chaúque Gouveia}

Mental Health Department, Public Health Directorate, Ministry of Health,

\section{Maria A. Oquendo}

University of Pennsylvania Perelman School of Medicine

\section{Cristiane S. Duarte}

New York State Psychiatric Institute

\section{Mohsin Sidat}

Department of Community Health, Faculty of Medicine, Eduardo Mondlane University (UEM)

Jair de Jesus Mari

Departamento de Psiquiatria, Escola Paulista de Medicina, Universidade Federal de São Paulo

\section{Milton L. Wainberg}

New York State Psychiatric Institute

\section{Research}

Keywords: Epilepsy, Community Health Workers, Knowledge, Attitudes, Practices, Primary Health Care, Mozambique

Posted Date: June 17th, 2020

DOI: https://doi.org/10.21203/rs.3.rs-35755/v1

License: () (1) This work is licensed under a Creative Commons Attribution 4.0 International License. Read Full License 


\section{Abstract}

Background: Epilepsy is the most common neurological disease in the world, affecting 50 million people, with the majority living in low- and middle-income countries (LMICs). A major focus of epilepsy treatment in LMICs has focused on task-sharing identification and epilepsy care by community health workers (CHWs). The present study aimed to assess the KAPs of CHWs towards epilepsy in Sofala province, Mozambique.

Methods: One hundred and thirty five CHWs completed a questionnaire that included socio-demographic characteristics and 44-items divided in six subscales pertaining to KAPs towards epilepsy (QKAP-EPI) in nine districts of Sofala Province, Mozambique. The internal consistency and factor structure were examined to evaluate the reliability and construct validity of the QKAP-EPI, respectively. To examine correlates of KAPs toward epilepsy we evaluated the association between sociodemographic variables and QKAP-EPI subscales using linear regression models.

Results: $\mathrm{CHWs}$ demonstrated adequate knowledge regarding epilepsy for medical treatment details (Mean=1.63, $S D=0.28$ ) and epilepsy safety/risks (Mean=1.62, SD=0.59). However, $C H W s$ reported low levels of knowledge related to the causes of epilepsy, espousing stigmatizing attitudes, as well as cultural treatment, which is the perception in different cultures of how epilepsy should be treated. Knowledge about how to manage epilepsy during crisis varied across the different types of emergency care practices. Heterogeneity in the level of knowledge regarding epilepsy was observed among CHWs in the different districts of Sofala Province and when using different local names of epilepsy (Dzumba, Nzwiti).

Conclusion: CHWs knowledge of medical treatment and epilepsy safety/risks were adequate. However, information on the causes of epilepsy, stigmatizing attitudes, cultural treatment, and some aspects of epileptic crisis response were low. These areas of poor knowledge should be the focus of educating CHWs in increasing their ability to provide quality care for patients with epilepsy in LMICs.

\section{Key Points}

- One Hundred and Thirty Five CHWs Completed a Questionnaire that Included Socio-Demographic Characteristics and 44-items Divided in Six Subscales Pertaining to KAPs Towards Epilepsy in Nine Districts of Sofala Province, Mozambique. - The Internal Consistency and Factor Structure Were Examined to Evaluate the Reliability and Construct Validity of the QKAP-EPI. · We Evaluated the Association Between Sociodemographic Variables and QKAP-EPI Subscales Using Linear Regression Models. CHWs Knowledge of Medical Treatment and Epilepsy Safety/Risks Were Adequate. However, Information on the Causes of Epilepsy, Stigmatizing Attitudes, Cultural Treatment, and Some Aspects of Epileptic Crisis Response Were Low. Heterogeneity in the level of Knowledge Regarding Epilepsy Was Observed Among CHWs in the Different Districts of Sofala Province and When Using Different Local Names of Epilepsy (Dzumba, Nzwiti).

\section{Background}

Epilepsy is the most common neurological disease in the world, affecting 50 million people, with the majority (85\%) living in low and middle-income countries (LMICs) of whom $80 \%$ do not receive appropriate treatment ${ }^{1-}$

3). The unavailability of treatment may be caused by lack of trained people and essential drugs or an 
inadequate care ${ }^{(3)}$. In Mozambique, neuropsychiatric disorders account for $23.1 \%$ of all Years Lived with Disability (YLD) in individuals aged 15-49 years $^{(4)}$, and epilepsy is the leading cause of outpatient mental health consultations, especially in rural areas ${ }^{(5-7)}$. The risk of premature death among people with epilepsy $(P W E)$ is up to three times higher than for the general population ${ }^{(8)}$. Epilepsy is a highly stigmatized condition, particularly because it is inaccurately considered contagious and stigmatized $(1,8,9)$. In low-resource settings, epilepsy is often perceived as a mental illness resulting from spiritual possession or witchcraft, making PWE more likely to seek traditional/spiritual treatment instead of medical treatment ${ }^{(10)}$. If proper diagnosis and treatment were provided, up to $70 \%$ of PWE would live seizure free. Globally, between $50-75 \%$ of PWE are not treated, despite treatment costing less than $\$ 5$ per year ${ }^{(11)}$. Task shifting of epilepsy diagnosis and management to community health workers (CHWs) can reduce the treatment gap ${ }^{(12)}$.

In 2014 the Mozambican Ministry of Health implemented a strategy of training CHWs to care for common health problems in regions with limited access to healthcare and placing at least one Psychiatric Technician at primary healthcare (PHC) facilities in all 135 districts nationally $(6,13)$. Supervised by Psychiatrists, Psychiatric Technicians are mid-level health professionals trained for promoting mental health prevention, diagnosis and treatment of common mental health disorders, including epilepsy at the PHC level in Mozambique. When properly trained, $\mathrm{CHWs}$ work closely with Psychiatric Technicians in addressing community awareness about mental health and establishing referrals from the community to $\mathrm{PHC}^{(13)}$.

There are multiple trials which have demonstrated that lay personnel can efficaciously treat common mental disorders using psychological interventions ${ }^{(14)}$, however, there is a paucity of published studies describing $\mathrm{CHWs}$ role in the promotion of epilepsy treatment and care in LMICs. Few published studies in Mozambique or other Sub-Saharan African countries explore CHWs knowledge, attitudes, and practices towards epilepsy. Most studies conducted in other African countries, related to epilepsy, have focused on health professionals, students or communities in general. A study assessing Zambian health professionals knowledge regarding epilepsy showed a knowledge gap among nurses (25\%) who often stated they would not allow their children to marry a person with epilepsy ${ }^{(15)}$, a finding similar to that reported in another study carried in Nigeria among community residents $^{(16)}$. Another qualitative study conducted in Congo, has shown that community misperceptions about PWE are common ${ }^{(17)}$. In contrast, a study performed in Bolivia showed that the nonmedical professionals (nurses, community health workers) presented good baseline knowledge, attitudes and beliefs related to epilepsy ${ }^{(18)}$. Like in many African countries, care delivered by Mozambican CHWs is often more culturally accepted and represents the first line of care in community settings ${ }^{(19)}$. They are also the first point of entry into PHC in Mozambique ${ }^{(20)}$. In Mozambique, however, most CHWs are not currently trained to have adequate knowledge, attitudes and practices towards epilepsy to allow them to recognize and refer PWE to PHC. To characterize $\mathrm{CHWs}$ existing knowledge, attitudes and practices towards epilepsy, this study aims to assess: (a) the reliability and validity of the QKAP-EPI among CHWs in Mozambique; (b) CHWs knowledge, attitudes, and practices towards epilepsy; and (c) socio-demographic correlates of knowledge, attitudes, and practices towards epilepsy.

\section{Study Methods}

\subsection{Structure of Mental Health Care Systems in Mozambique}


The National Mental Health Program is under the management of the Department of Mental Health at the Ministry of Health. The Provincial Mental Health Program organizes the districts data and reports to the National Mental Health Program in Ministry of Health (MISAU)(21). The country has 25 Psychiatrists (only 18 of which are Mozambican), 305 Psychiatric Technicians, 130 Clinical Psychologists, and 14 Occupational Therapists who provide services to only $7.2 \%$ of the public clinics (Mental Health Department, MISAU, 2019). Since the 1990s, Mozambique has been a leader at Sub-Saharan Africa in training mental health professionals (Psychiatric Technicians) to provide treatment for all categories of mental illness $(13,21,22)$.

\subsection{Study Design and Setting}

This cross-sectional study was conducted from January 2018 to July 2018 to assess CHWs knowledge, attitudes and practices towards epilepsy in PHC in the province of Sofala. Sofala is a mostly rural province (59.1\%) located in the central region of Mozambique with a population of 2,221,803 inhabitants and an illiteracy rate of $43.1 \%$. There are 161 health facilities distributed across 13 districts of Sofala ${ }^{(23)}$ providing PHC and epilepsy care. Mental health and epilepsy services are available in 25 health facilities with a coverage of $15 \%$ of the province ${ }^{(24)}$. The majority of mental health services are located in the district-level facilities, except Beira City which has mental health services in 11 out of its 20 health facilities $^{(24)}$.

1. 2.3 Study Participants and Procedures: Fifteen CHWs were selected from nine districts (total $n=135)$ in Sofala province (Fig. 1). Districts were included if they had no previous implementation of World Health Organization Mental Health Gap Action Plan (WHO mhGAP) and had no trained CHWs in the detection and management of epilepsy cases. A maximum of $20 \mathrm{CHWs}$ are allocated to each district - if districts had more than $15 \mathrm{CHWs}$ we randomly selected 15 from the larger group. The lead $\mathrm{CHW}$ in each health facility invited all $\mathrm{CHWs}$ at that health facility to participate in the study. Participants were included if they were 18 years or older, belonged to the district headquarters, were fluent in Portuguese, and provided written informed consent.

\section{2.4 Study Instruments}

The sociodemographic questionnaire administered to the participants included the variables such as gender, age, education, marital status, religion, occupation, and residence. The CHWs knowledge, attitudes and practices towards epilepsy were evaluated through the QKAP - EPI (Questionnaire of Knowledge, Attitudes, and Practices towards Epilepsy). The QKAP - EPI was translated from English to Portuguese, back translated and adapted to the context of Sofala Province from a Kenyan version ${ }^{(25)}$. To the original scale had 5 subscales with 38 questions, we added an additional subscale of practices during crisis including 6 items. Thus, the questionnaire contains 44 items, divided into 6 subscales: Causes of Epilepsy, Medical Treatment, Cultural Treatment, Risks and Safety, Attitudes towards PWE, Practices During an Epileptic Crisis. Response options are in the form of a 3-point Likert scale, ranging from 0 (I do not believe), 1 (I believe very little), to 2 (I believe very much). The questionnaire was completed on average between 15-20 minutes. A higher score reflects a positive Knowledge, Attitudes and Practices about epilepsy. The higher score on items 1-14, 24-27, 43 and 44 reflects positive knowledge, attitudes and practices about epilepsy. Lower score of the items 15-23 and 28-42 reflects positive knowledge, attitudes and practices appropriate for epilepsy. Total score ranges from 0 to 88 points (See Table 2).

\subsection{Ethical Issues}


Written consent was obtained from all eligible participants. The CHWs were assured their participation was voluntary and it would not affect their work. Approval for the study was obtained from the Eduardo Mondlane University (Medical School) \& Maputo Central Hospital Ethical Review Committee under registration CIBS FM\&HCM/74/2016.

\subsection{Data Analysis}

Descriptive analyses including the mean and the standard deviation (SD) for continuous demographic variables (e, g., age) and frequencies for categorical demographic variables (e, g., occupation, marital status, and schooling level achieved) were calculated to characterize the full sample of community health workers. We estimated the internal consistency of subscales using Ordinal alpha coefficients. We evaluated the internal construct validity of the QKAP-EPI using a confirmatory factor analysis. Fit of the model was evaluated using the RMSEA (Root Mean Square Error of Approximation), CFI (Comparative Fit Index), TLI (Tucker Lewis Index), SRMR (Standardized Root Mean Residua), and examination of the factor loadings and modification indices. The correlation between subscales was calculated using Pearson correlation coefficients. We used linear regression to examine demographic correlates of each subscale score including age, sex, marital status,

schooling level achieved, occupation, religious affiliation, and district as covariates. Significance level was set at 0.05. All analyses were conducted in Stata 14.

\section{Results}

\subsection{Sample Description}

Of the $135 \mathrm{CHWs}$, most were male (69.3\%), had a secondary or higher education level (55.6\%), were Christian (70.4\%), and either primarily unemployed (43.7\%) or a farmer (23.0\%). The average age was 38 years. (SD = 13.01; Table 1).

\subsection{Internal Consistency of Knowledge, Attitudes, Practices Regarding Epilepsy Subscales and Items with Low Item Rest Correlation}

The internal consistency of the subscale Practices During Crisis was low $(a=0.238)$. The internal consistency was moderate for 2 subscales (Causes of Epilepsy, $a=0.65$; Medical Treatment, $a=0.694$ ), acceptable for Cultural Treatment $(a=0.797)$ and excellent for Safety and Risks $(\alpha=0.926)$ and Negative Attitudes $(a=0.904)$. The overall ordinal alpha was not reported because the adapted questionnaire of knowledge, attitudes and practices is a multidimensional scale. Several subscales contained item(s) that were not strongly correlated with other items in the subscale, suggesting that they may be less informative or specific to the subscale construct $^{(26)}$; (Table 3).

To examine the fit of the 6-factor model of knowledge, attitudes, and practices, we conducted a confirmatory factor analysis. The fit of the original model was poor (RMSEA $=0.075,90 \% \mathrm{Cl}: 0.069,0.081 ; \mathrm{CFI}=0.582 ; \mathrm{TLI}=$ 0.553 ; SRMR $=0.103)$, primarily due to the multidimensionality of the subscale practices during crisis. The first three items (We Should Put a Stick in the Mouth of the PWE During Seizures; We Should Give a Drink to the PWE During Seizures; We Should Stay Away from PWE During Seizures) most strongly loaded on the first factor, now referred to as Practices of Sticking into a Mouth, Give a Drink, Stay Away. The last three items (We Should Hold PWE During Seizures to Stop Seizures; We Must Help PWE During the Seizures Not to Hit the Head on the 
Ground; We Must Place the PWE in the Right Lateral Safety Position to Avoid Aspiration) most strongly loaded on the second factor, now referred to as Practices of Holding, Helping, Placing in Safety Position. Dividing the practices during crisis subscale into two factors and estimating the covariance of highly correlated items improved the model to displaying adequate fit (RMSEA $=0.059,90 \% \mathrm{Cl}: 0.051,0.066 ; \mathrm{CFI}=0.749 ; \mathrm{TLI}=0.727$; SRMS = 0.098). The item, "we should stay away from PWE during seizures", from the added "Sticking into a Mouth, Give a Drink, and Staying Away" during crisis subscale loaded slightly more strongly on the Negative Attitudes subscale. Although allowing cross-loading of this item onto both the "Sticking into a Mouth, Give a Drink, and Staying Away" during crisis and the Negative Attitudes subscale would have slightly improved the fit, the benefits were not substantial and may not offset the complexity introduced to scoring the QKAP-EPI and deviating from the original item domains.

\subsection{CHWs Responses to the Adapted Questionnaire of Knowledge, Attitudes, Practices Towards Epilepsy}

Most of the CHWs very much believed that causes of epilepsy may be related to head injury (59.26\%), malaria/meningitis/fever (45.93\%), brain injury (54.81\%) and is accordingly to the literature, but some did not believe that it can be inherited (52.59\%) or related to childbirth injury (54.81\%), denoting a lack of knowledge regarding these two items. They also did believe very much that epilepsy can be treated (77.04\%) and it should be done in a regular basis to better control the disease $(77.78 \%)$, all the conditions of epilepsy with local names (Nzwite, Njiri Njiri) are best treated by a doctor (75.56\%; 71.85\%), antiepileptic medicines control the seizures $(71.85 \%)$ and that these medicines can be available in health facilities (88.15\%.), demonstrating a positive knowledge regarding the medical treatment of epilepsy.

In the "Cultural Treatment" subscale, a number of CHWs endorsed false cures or treatments for epilepsy. For example, $51 \%$ of $\mathrm{CHWs}$ believe that if a PWE burns when set on fire, this means this person cannot be cured from epilepsy. Further, $21 \%$ believed that during an epileptic crisis, it would be appropriate to put water on the person or make the person smell some one's shoes. Lastly, $23 \%$ believed that putting a stick in someone's mouth during a seizure can treat epilepsy. More than half of $\mathrm{CHWs}$ believed that some forms of epilepsy with local names (Dzumba) can be treated while other forms (Nzwiti) cannot be treated (52.59\%) demonstrating a negative knowledge of cultural treatment and the different interpretation of the different names of epilepsy when related to treatment. It was also found that more than half of the CHWs believe that legs of a PWE should be stretched during seizures (52.59\%) which goes against the epilepsy treatment protocol.

In the Safety and Risks subscale, more than half of the CHWs believed very much that PWE should: not climb trees $(74.04 \%)$, not drive (70.37\%), avoid fire (85.19\%) or water sites (79.26\%), which demonstrates positive knowledge, attitudes and practices towards epilepsy in safety and risks. More than half of the CHWs demonstrated low levels of negative attitudes and did believed that PWE should: get married (65.93\%), go to school (71.85\%) or have a job (74.04\%).

Most of the CHWs did not believe that one should put a stick in people's mouths (73.33\%), give a drink (78.52\%), stay away (71.11\%) from PWE during crises, demonstrating a positive knowledge. However, more than half of CHWs believed that we should hold people during seizures to stop them (67.7\%) which goes against the epilepsy treatment protocols. (Table 2) 


\subsection{Average of subscales and Correlation Between Subscales of the Adapted Questionnaire of Knowledges, Attitudes and Practices Towards Epilepsy}

The average of subscales, which ranged from 0 (no knowledge) to 2 (good knowledge), were adequate for the following subscales: Medical Treatment $(M=1.63, S D=0.28)$, Safety and Risks $(M=1.62, S D=0.59)$, Practices of Holding, Helping, and Placing in Safety Position During Crisis ( $M=1.60, S D=0.48)$. The average of Subscales Causes of Epilepsy $(M=1.10, S D=0.53)$, Cultural Treatment $(M=1.48, S D=0.39)$, Negative Attitudes ( $M=1.47, S D=0.48)$, and Practices of Sticking into a Mouth, Give a Drink, Stay Away During Crisis ( $M=1.43, S D$ $=0.42$ ) were slightly lower indicating less knowledge. Correlations between subscales revealed that knowledge about the causes of epilepsy, medical treatment, and sticking into a mouth, giving a drink, and staying away during crisis were not strongly correlated with other subscales $(r<0.250)$. Knowledge about cultural treatment was moderately correlated with knowledge about negative attitudes toward epilepsy $(r=0.392)$ and strongly correlated with holding, helping, placing in safety position during crisis $(r=0.575)$. Safety and risks knowledge were also moderately correlated with negative attitudes $(r=0.319)$. The holding, helping, and placing in safety position during crisis subscale was weakly correlated with subscale safety and risks $(r=0.204)$ and negative attitudes ( $r=0.254)$; (Table 04).

\subsection{Association Between Demographic Characteristic (Sex, Schooling Level Achieved, Religion, Civil Status) and 6 Subscales of Adapted QKAP Towards Epilepsy}

The linear regression revealed differences in knowledge when analyzing by sociodemographic variables.

Knowledge about "causes of epilepsy" was higher among the employed relative to those unemployed $(b=0.34$, $95 \% \mathrm{Cl}: 0.13,0.56)$. Knowledge about "cultural treatment" was lower among farmers ( $b=-0.21,95 \% \mathrm{Cl}:-0.40$, $-0.01)$ and those with other primary occupation $(b=-0.26,95 \% \mathrm{Cl}:-0.44,-0.09)$, relative to unemployed $\mathrm{CHWs}$. Knowledge about "medical treatment" was slightly higher among people of older age ( $b=0.01,95 \% \mathrm{Cl}: 0.00$, $0.01)$, higher among those in a common law marriage $(b=0.16,95 \% \mathrm{Cl}: 0.03,0.28)$, or who were divorced $(b=$ $0.32,95 \% \mathrm{Cl}: 0.02,0.63)$, compared to single. The knowledge about "safety and risks" was lower among divorced ( $b=-1.85,95 \%$ Cl: $-2.55,-1.15)$ relative to single CHWs. Knowledge about "Sticking into a Mouth, Give a Drink, and Staying Away During Crisis" was lower among females (vs. males; $b=-0.45,95 \% \mathrm{Cl}:-0.70,-0.20)$. In general, there was a difference in each of the 6 subscale scores when comparing the different nine districts. Total score across all subscales on the QKAP-EPI was significantly higher in Maringue relative to Caia district (b $=0.27,95 \% \mathrm{Cl}: 0.03,0.52)$, but did not differ by any other sociodemographic factors (Table 05$)$. 
Table 4

Average of subscales and Pearson correlation ( $r$ ) between subscales of Questionnaire of Knowledges, Attitudes and Practices Towards Epilepsy in Sofala, Mozambique

\begin{tabular}{|c|c|c|c|c|c|c|c|c|}
\hline & $\begin{array}{l}\text { Mean } \\
\text { (SD) }\end{array}$ & (1) & (2) & (3) & (4) & (5) & (6) & (7) \\
\hline 1) Causes of Epilepsy & $\begin{array}{l}1.10 \\
(0.53)\end{array}$ & - & & & & & & \\
\hline 2) Medical Treatment & $\begin{array}{l}1.63 \\
(0.28)\end{array}$ & 0.170 & - & & & & & \\
\hline 3) Cultural Treatment & $\begin{array}{l}1.48 \\
(0.39)\end{array}$ & -0.213 & 0.007 & - & & & & \\
\hline 4) Safety and Risks & $\begin{array}{l}1.62 \\
(0.59)\end{array}$ & -0.078 & 0.159 & 0.108 & - & & & \\
\hline 5) Negative Attitudes & $\begin{array}{l}1.47 \\
(0.48)\end{array}$ & -0.118 & -0.071 & 0.392 & 0.319 & - & & \\
\hline $\begin{array}{l}\text { 6) Practices of Sticking into a } \\
\text { Mouth, Give a Drink, Stay Away }\end{array}$ & $\begin{array}{l}1.43 \\
(0.42)\end{array}$ & -0.007 & 0.132 & 0.174 & 0.141 & 0.151 & - & \\
\hline $\begin{array}{l}\text { 7) Practices of Holding, Helping, } \\
\text { Placing in Safety Position }\end{array}$ & $\begin{array}{l}1.60 \\
(0.48)\end{array}$ & -0.109 & 0.054 & 0.575 & 0.204 & 0.254 & 0.086 & - \\
\hline *significance level: $p$ value $<0.05$ & & & & & & & & \\
\hline
\end{tabular}


Table 01

Sociodemographic Variables of Community Health Workers in Nine Districts of Sofala Province, Mozambique

\begin{tabular}{|c|c|c|c|}
\hline Variables & Categories & $n(\%)$ & $M \pm S D$ \\
\hline \multirow[t]{5}{*}{ Age } & $20-30$ & $45(33,33)$ & $38,22 \pm 13.01$ \\
\hline & $31-40$ & $41(30,37)$ & \\
\hline & $41-50$ & $15(11,11)$ & \\
\hline & $>50$ & $33(24,44)$ & \\
\hline & Missing & $1(0,74)$ & \\
\hline \multirow[t]{3}{*}{ Sex } & Male & $94(69,63)$ & \\
\hline & Female & $40(29,63)$ & \\
\hline & Missing & $1(0,74)$ & \\
\hline \multirow[t]{6}{*}{ Civil Status } & Single & $47(34,81)$ & \\
\hline & Married & $18(13,33)$ & \\
\hline & Common Law Marriage & $58(42,96)$ & \\
\hline & Divorced & $3(2,22)$ & \\
\hline & Separated & $7(5,19)$ & \\
\hline & Widow & $2(1,48)$ & \\
\hline \multirow[t]{3}{*}{ Schooling Level Achieved } & Primary & $44(32,59)$ & \\
\hline & Secondary or High & $75(55,56)$ & \\
\hline & Missing & $16(11,85)$ & \\
\hline \multirow[t]{4}{*}{ Primary Occupation } & Unemployed & $63(46,67)$ & \\
\hline & Farmer & $31(22,96)$ & \\
\hline & Other (e.g., Students, Teacher, Trader) & $40(29,63)$ & \\
\hline & Missing & $1(0,74)$ & \\
\hline \multirow[t]{3}{*}{ Religion } & Christian & $95(70,37)$ & \\
\hline & Other Religion & $36(26,67)$ & \\
\hline & Missing & $4(2,96)$ & \\
\hline
\end{tabular}


Table 02

Proportion of Response of Each Item of CHWs Knowledge, Attitudes, Practices of Epilepsy in Sofala Districts, 2018

Item of Each Scale

\section{Causes of Epilepsy}

1.Epilepsy is Inherited

2. Head Injury

3. Childbirth Injury

4. Malaria/Meningitis/Fever

5. Brain Injury

Medical Treatment
6. Possible to Treat Epilepsy

7. Antiepileptic Medicines Should Be Taken Continuously to Function Properly

8. Antiepileptic Medicines Are Available at the Health Facilities

9. Njiri Njiri* is Best Treated by a Doctor

10. PWE Should Be Placed in a Safe Place During the Seizures

11. Antiepileptic Medicines Control Seizures

12. Lack of Antiepileptic Medicines May Precipitate Seizures on PWE

13. Nzwite ${ }^{\star}$ is Best treated By a Doctor

14.Antiepileptic Medicines May Cause Side Effects

\section{Cultural Treatment}

15. PWE that Burn Will Never Be Cured

16. Dzumba*Can Be Treated Unlike Nzwite

\section{Don't \\ Believe $\mathrm{n}$ \\ (\%)}

Believe a Totally Little n (\%) Believe n (\%)

\begin{tabular}{|c|c|c|}
\hline $71(52.59)$ & $20(14.81)$ & 44 (32.59) \\
\hline $\begin{array}{l}36 \\
(26.67)\end{array}$ & 19 (14.07) & $80(59.26)$ \\
\hline $58(42.96)$ & $26(19.26)$ & $51(37.78)$ \\
\hline $\begin{array}{l}50 \\
(37.04)\end{array}$ & $23(17.04)$ & $62(45.93)$ \\
\hline $\begin{array}{l}28 \\
(20.74)\end{array}$ & $33(24.44)$ & $74(54.81)$ \\
\hline
\end{tabular}

$12(8.89)$

12 (8.89)

7 (5.19)

18

(13.33)

$3(2.22)$

$0(0.0)$

$22(16.30)$

(11.85)

17

(12.59)

17

(12.59)

42

(31.11)

$20(14.81)$

$9(6.67)$

$20(14.81)$

$38(28.15)$
104 (77.04)

105 (77.78)

119 (88.15)

$97(71.85)$

$132(97.78)$

97 (71.85)

98 (72.59)

$16(11.85) \quad 102(75.56)$

$55(40.74)$

69

$(51.11)$

$21(15.56)$

$45(33.33)$

64

(47.41)
$39(28.89)$

*Njiri Njiri, Nzwite, Dzumba, Guru, Dwiti. **Nhanga. 


\begin{tabular}{|c|c|c|c|}
\hline Item of Each Scale & $\begin{array}{l}\text { I Don't } \\
\text { Believe n } \\
(\%)\end{array}$ & $\begin{array}{l}\text { Believe a } \\
\text { Little n (\%) }\end{array}$ & $\begin{array}{l}\text { Totally } \\
\text { Believe n (\%) }\end{array}$ \\
\hline 17. Guru* is Best Treated by a Nhanga & $\begin{array}{l}94 \\
(69.63)\end{array}$ & $25(18.52)$ & $16(11.85)$ \\
\hline 18. Spreading Water in PWE During Seizures Treats Epilepsy & $\begin{array}{l}107 \\
(79.26)\end{array}$ & $16(11.85)$ & $12(8.89)$ \\
\hline $\begin{array}{l}\text { 19. Make Smell Shoes to PWE, During Seizures Treats } \\
\text { Epilepsy }\end{array}$ & $\begin{array}{l}107 \\
(79.26)\end{array}$ & $16(11.85)$ & $12(8.89)$ \\
\hline 20. Fumigation Treats Epilepsy & $\begin{array}{l}109 \\
(80.74)\end{array}$ & $12(8.89)$ & $14(10.37)$ \\
\hline $\begin{array}{l}\text { 21. It is Good to Put a Stick in the Mouth of the PWE During } \\
\text { Seizures }\end{array}$ & $\begin{array}{l}104 \\
(77.04)\end{array}$ & $12(8.89)$ & 19 (14.07) \\
\hline 22. Legs of a PWE Should Be Stretched During Seizures & $\begin{array}{l}64 \\
(47.41)\end{array}$ & $28(20.74)$ & $43(31.85)$ \\
\hline 23. Dwiti* is Best Treated by a Nhanga** & $\begin{array}{l}84 \\
(62.22)\end{array}$ & $33(24.44)$ & $18(13.33)$ \\
\hline \multicolumn{4}{|l|}{ Safety and Risks } \\
\hline 24. PWE Should Not Climb the Trees & $\begin{array}{l}26 \\
(19.26)\end{array}$ & $9(6.67)$ & $100(74.04)$ \\
\hline 25. PWE Should Not Drive & $\begin{array}{l}25 \\
(18.52)\end{array}$ & $15(11.11)$ & $95(70.37)$ \\
\hline 26. PWE Should Avoid Being Near the Fire & $\begin{array}{l}15 \\
(11.11)\end{array}$ & $5(3.70)$ & $115(85.19)$ \\
\hline 27.PWE Should Avoid Staying in Places Near Water & $\begin{array}{l}17 \\
(12.59)\end{array}$ & $11(8.15)$ & $107(79.26)$ \\
\hline \multicolumn{4}{|l|}{ Negative Attitudes } \\
\hline 28. PWE Should Not or Can Not Get Married & $\begin{array}{l}89 \\
(65.93)\end{array}$ & $14(10.37)$ & $32(23.70)$ \\
\hline 29. PWE Should Not Go to School & $\begin{array}{l}97 \\
(71.85)\end{array}$ & $8(5.93)$ & $30(22.22)$ \\
\hline 30. PWE Should Not or Can Not Have a Job & $\begin{array}{l}100 \\
(74.04)\end{array}$ & $13(9.63)$ & $22(16.3)$ \\
\hline 31. PWE Should Not or Can Not Have a Normal Life & $\begin{array}{l}83 \\
(61.48)\end{array}$ & $17(12.59)$ & $35(25.93)$ \\
\hline 32. PWE Should Be Isolated & $\begin{array}{l}109 \\
(80.74)\end{array}$ & $8(5.93)$ & $18(13.33)$ \\
\hline 33. PWE Should Be Rejected & $\begin{array}{l}109 \\
(80.74)\end{array}$ & $12(8.89)$ & $14(10.37)$ \\
\hline
\end{tabular}

*Njiri Njiri, Nzwite, Dzumba, Guru, Dwiti. **Nhanga. 


\begin{tabular}{|c|c|c|c|}
\hline Item of Each Scale & $\begin{array}{l}\text { I Don't } \\
\text { Believe n } \\
(\%)\end{array}$ & $\begin{array}{l}\text { Believe a } \\
\text { Little n (\%) }\end{array}$ & $\begin{array}{l}\text { Totally } \\
\text { Believe n (\%) }\end{array}$ \\
\hline 34. PWE Should Be Offended & $\begin{array}{l}112 \\
(82.96)\end{array}$ & $9(6.67)$ & $14(10.37)$ \\
\hline 35. PWE are Burden for Society and Family & $\begin{array}{l}74 \\
(54.81)\end{array}$ & $22(16.30)$ & $39(28.89)$ \\
\hline 36. PWE Performs Poorly at School & $\begin{array}{l}68 \\
(50.37)\end{array}$ & $34(25.19)$ & $33(24.44)$ \\
\hline 37. PWE Gives a Lot of Work & $\begin{array}{l}70 \\
(51.85)\end{array}$ & $27(20.00)$ & $38(28.15)$ \\
\hline 38. PWE Are Crazy & $\begin{array}{l}84 \\
(62.22)\end{array}$ & $23(17.04)$ & $28(20.74)$ \\
\hline \multicolumn{4}{|l|}{ Practices During Crisis } \\
\hline $\begin{array}{l}\text { 39. We Should Put a Stick in the Mouth of the PWE During } \\
\text { Seizures }\end{array}$ & $\begin{array}{l}99 \\
(73.33)\end{array}$ & $14(10.37)$ & $22(16.30)$ \\
\hline 40. We Should Give a Drink to the PWE During Seizures & $\begin{array}{l}106 \\
(78.52)\end{array}$ & $17(12.59)$ & $12(8.89)$ \\
\hline 41. We Should Stay Away from PWE During Seizures & $\begin{array}{l}96 \\
(71.11)\end{array}$ & $14(10.37)$ & $25(18.52)$ \\
\hline 42. We Should Hold PWE During Seizures to Stop Seizures & $\begin{array}{l}44 \\
(32.59)\end{array}$ & $21(15.85)$ & $70(51.85)$ \\
\hline $\begin{array}{l}\text { 43. We Must Help PWE During the Seizures Not to Hit the } \\
\text { Head on the Ground }\end{array}$ & $\begin{array}{l}14 \\
(10.37)\end{array}$ & $6(4.44)$ & $115(85.19)$ \\
\hline $\begin{array}{l}\text { 44. We Must Place the PWE in the Right Lateral Safety } \\
\text { Position to Avoid Aspiration }\end{array}$ & $12(8.89)$ & $13(9.63)$ & $110(81.48)$ \\
\hline
\end{tabular}


Table 03

- Internal Consistency in the Subscales of the Adapted Questionnaire of Knowledge, Attitudes, Practices Towards Epilepsy and Items with Low Item Rest Correlation

\begin{tabular}{|c|c|c|}
\hline Subscale & $\begin{array}{l}\text { Ordinal } \\
\text { alpha }\end{array}$ & $\begin{array}{l}\text { Items with Low Item- } \\
\text { Rest Correlation }\end{array}$ \\
\hline Causes of epilepsy & 0.650 & Epilepsy is inherited \\
\hline \multirow{3}{*}{$\begin{array}{l}\text { Medical treatment } \\
\text { *Note: removed item } 10 \text { from internal consistency calculation because } \\
\text { not all responses endorsed and polychoric correlation matrix would not } \\
\text { converge }\end{array}$} & \multirow[t]{3}{*}{0.694} & Antiepileptic \\
\hline & & cause side effects \\
\hline & & $\begin{array}{l}\text { Nzwite is best treated } \\
\text { by a doctor }\end{array}$ \\
\hline \multirow[t]{2}{*}{ Cultural treatment } & \multirow[t]{2}{*}{0.797} & $\begin{array}{l}\text { PWE that burn will } \\
\text { never be cured }\end{array}$ \\
\hline & & $\begin{array}{l}\text { Legs of a PWE Should } \\
\text { Be Stretched During } \\
\text { Seizures }\end{array}$ \\
\hline Safety and risks & 0.926 & - \\
\hline Negative attitudes & 0.904 & - \\
\hline \multirow[t]{2}{*}{ Practices during crisis } & \multirow[t]{2}{*}{0.238} & $\begin{array}{l}\text { We Should Stay Away } \\
\text { from PWE During } \\
\text { Seizures }\end{array}$ \\
\hline & & $\begin{array}{l}\text { We Should Hold PWE } \\
\text { During Seizures to } \\
\text { Stop Seizures }\end{array}$ \\
\hline
\end{tabular}


Table 05

- Association between demographic characteristic (Sex, Schooling Level Achieved, Religion, Civil Status) and Subscales-QKAP; B $(95 \% \mathrm{Cl})$

\begin{tabular}{|c|c|c|c|c|c|c|c|c|}
\hline & $\begin{array}{l}\text { Causes } \\
\text { of } \\
\text { epilepsy }\end{array}$ & $\begin{array}{l}\text { Medical } \\
\text { treatment }\end{array}$ & $\begin{array}{l}\text { Cultural } \\
\text { treatment }\end{array}$ & $\begin{array}{l}\text { Safety } \\
\text { and } \\
\text { risks }\end{array}$ & $\begin{array}{l}\text { Negative } \\
\text { attitudes }\end{array}$ & $\begin{array}{l}\text { Practices } \\
\text { during } \\
\text { crisis A }\end{array}$ & $\begin{array}{l}\text { Practices } \\
\text { during } \\
\text { crisis B }\end{array}$ & $\begin{array}{l}\text { Total } \\
\text { Score }\end{array}$ \\
\hline \multirow[t]{2}{*}{ Age } & 0.00 & 0.01 & 0.00 & 0.00 & 0.00 & -0.00 & -0.01 & 0.00 \\
\hline & $\begin{array}{l}(-0.01 \\
0.01)\end{array}$ & $\begin{array}{l}(0.00 \\
0.01)\end{array}$ & $\begin{array}{l}(-0.01 \\
0.00)\end{array}$ & $\begin{array}{l}(-0.01 \\
0.01)\end{array}$ & $\begin{array}{l}(-0.01 \\
0.01)\end{array}$ & $\begin{array}{l}(-0.01 \\
0.01)\end{array}$ & $\begin{array}{l}(-0.02 \\
0.00)\end{array}$ & $\begin{array}{l}(0.00, \\
0.01)^{\prime}\end{array}$ \\
\hline \multirow{2}{*}{$\begin{array}{l}\text { Female (ref } \\
=\text { Male) }\end{array}$} & 0.04 & 0.12 & -0.12 & 0.15 & -0.20 & -0.00 & -0.45 & -0.06 \\
\hline & $\begin{array}{l}(-0.19 \\
0.27)\end{array}$ & $\begin{array}{l}(0.00 \\
0.24)\end{array}$ & $\begin{array}{l}(-0.31 \\
0.06)\end{array}$ & $\begin{array}{l}(-0.13, \\
0.42)\end{array}$ & $\begin{array}{l}(-0.44, \\
0.04)\end{array}$ & $\begin{array}{l}(-0.23, \\
0.22)\end{array}$ & $\begin{array}{l}(-0.70 \\
-0.20)\end{array}$ & $\begin{array}{l}(-0.17 \\
0.06)\end{array}$ \\
\hline \multicolumn{9}{|l|}{$\begin{array}{l}\text { Marital } \\
\text { Status (ref = } \\
\text { Single) }\end{array}$} \\
\hline \multirow[t]{2}{*}{ Married } & -0.07 & 0.00 & 0.01 & -0.35 & 0.00 & 0.16 & -0.02 & -0.04 \\
\hline & $\begin{array}{l}(-0.37 \\
0.24)\end{array}$ & $\begin{array}{l}(-0.16 \\
0.15)\end{array}$ & $\begin{array}{l}(-0.23, \\
0.26)\end{array}$ & $\begin{array}{l}(-0.71 \\
0.01)\end{array}$ & $\begin{array}{l}(-0.32 \\
0.31)\end{array}$ & $\begin{array}{l}(-0.13 \\
0.45)\end{array}$ & $\begin{array}{l}(-0.34 \\
0.30)\end{array}$ & $\begin{array}{l}(-0.19 \\
0.11)\end{array}$ \\
\hline \multirow{2}{*}{$\begin{array}{l}\text { Common } \\
\text { Law } \\
\text { Marriage }\end{array}$} & 0.13 & 0.16 & -0.04 & 0.10 & -0.13 & 0.12 & -0.22 & 0.01 \\
\hline & $\begin{array}{l}(-0.10 \\
0.37)\end{array}$ & $\begin{array}{l}(0.03, \\
0.28)\end{array}$ & $\begin{array}{l}(-0.23, \\
0.15)\end{array}$ & $\begin{array}{l}(-0.18 \\
0.38)\end{array}$ & $\begin{array}{l}(-0.37 \\
0.11)\end{array}$ & $\begin{array}{l}(-0.10 \\
0.35)\end{array}$ & $\begin{array}{l}(-0.47, \\
0.03)\end{array}$ & $\begin{array}{l}(-0.11, \\
0.12)\end{array}$ \\
\hline \multirow[t]{2}{*}{ Divorced } & 0.54 & 0.32 & 0.14 & -1.85 & 0.19 & 0.25 & 0.09 & 0.03 \\
\hline & $\begin{array}{l}(-0.06, \\
1.14)\end{array}$ & $\begin{array}{l}(0.02, \\
0.63)\end{array}$ & $\begin{array}{l}(-0.34 \\
0.62)\end{array}$ & $\begin{array}{l}(-2.55 \\
-1.15)\end{array}$ & $\begin{array}{l}(-0.42 \\
0.81)\end{array}$ & $\begin{array}{l}(-0.31 \\
0.81)\end{array}$ & $\begin{array}{l}(-0.52 \\
0.71)\end{array}$ & $\begin{array}{l}(-0.26 \\
0.32)\end{array}$ \\
\hline \multirow[t]{2}{*}{ Separated } & 0.41 & 0.04 & -0.10 & -0.29 & -0.19 & -0.06 & 0.09 & -0.04 \\
\hline & $\begin{array}{l}(0.00, \\
0.82)\end{array}$ & $\begin{array}{l}(-0.17 \\
0.25)\end{array}$ & $\begin{array}{l}(-0.44 \\
0.23)\end{array}$ & $\begin{array}{l}(-0.77 \\
0.20)\end{array}$ & $\begin{array}{l}(-0.61 \\
0.24)\end{array}$ & $\begin{array}{l}(-0.42, \\
0.30)\end{array}$ & $\begin{array}{l}(-0.31 \\
0.48)\end{array}$ & $\begin{array}{l}(-0.25, \\
0.16)\end{array}$ \\
\hline \multirow[t]{2}{*}{ Widow } & 0.24 & 0.00 & 0.56 & -0.12 & 0.52 & 0.62 & 0.47 & 0.32 \\
\hline & $\begin{array}{l}(-0.49 \\
0.96)\end{array}$ & $\begin{array}{l}(-0.38 \\
0.37)\end{array}$ & $\begin{array}{l}(-0.02 \\
1.14)\end{array}$ & $\begin{array}{l}(-0.97 \\
0.74)\end{array}$ & $\begin{array}{l}(-0.22 \\
1.27)\end{array}$ & $\begin{array}{l}(-0.03, \\
1.28)\end{array}$ & $\begin{array}{l}(-0.25, \\
1.19)\end{array}$ & $\begin{array}{l}(-0.04, \\
0.67)\end{array}$ \\
\hline \multirow{2}{*}{$\begin{array}{l}\text { Secondary } \\
\text { school or } \\
\text { higher (ref = } \\
\text { Primary } \\
\text { school) }\end{array}$} & 0.00 & 0.08 & 0.08 & 0.07 & 0.18 & 0.06 & -0.05 & 0.08 \\
\hline & $\begin{array}{l}(-0.23, \\
0.22)\end{array}$ & $\begin{array}{l}(-0.04, \\
0.19)\end{array}$ & $\begin{array}{l}(-0.10 \\
0.25)\end{array}$ & $\begin{array}{l}(-0.19 \\
0.33)\end{array}$ & $\begin{array}{l}(-0.04 \\
0.41)\end{array}$ & $\begin{array}{l}(-0.13 \\
0.25)\end{array}$ & $\begin{array}{l}(-0.26 \\
0.16)\end{array}$ & $\begin{array}{l}(-0.03, \\
0.19)\end{array}$ \\
\hline \multicolumn{9}{|l|}{$\begin{array}{l}\text { Occupation } \\
\text { (ref = } \\
\text { Unemployed) }\end{array}$} \\
\hline \multirow[t]{2}{*}{ Farmer } & 0.18 & 0.09 & -0.21 & 0.17 & -0.13 & -0.20 & -0.10 & -0.05 \\
\hline & $\begin{array}{l}(-0.06 \\
0.41)\end{array}$ & $\begin{array}{l}(-0.03, \\
0.21)\end{array}$ & $\begin{array}{l}(-0.40 \\
-0.01)\end{array}$ & $\begin{array}{l}(-0.11, \\
0.44)\end{array}$ & $\begin{array}{l}(-0.38, \\
0.11)\end{array}$ & $\begin{array}{l}(-0.48, \\
0.08)\end{array}$ & $\begin{array}{l}(-0.40, \\
0.21)\end{array}$ & $\begin{array}{l}(-0.16 \\
0.07)\end{array}$ \\
\hline
\end{tabular}




\begin{tabular}{|c|c|c|c|c|c|c|c|c|}
\hline & $\begin{array}{l}\text { Causes } \\
\text { of } \\
\text { epilepsy }\end{array}$ & $\begin{array}{l}\text { Medical } \\
\text { treatment }\end{array}$ & $\begin{array}{l}\text { Cultural } \\
\text { treatment }\end{array}$ & $\begin{array}{l}\text { Safety } \\
\text { and } \\
\text { risks }\end{array}$ & $\begin{array}{l}\text { Negative } \\
\text { attitudes }\end{array}$ & $\begin{array}{l}\text { Practices } \\
\text { during } \\
\text { crisis A }\end{array}$ & $\begin{array}{l}\text { Practices } \\
\text { during } \\
\text { crisis B }\end{array}$ & $\begin{array}{l}\text { Total } \\
\text { Score }\end{array}$ \\
\hline \multirow[t]{2}{*}{ Other } & 0.34 & 0.00 & -0.26 & 0.08 & -0.08 & -0.03 & -0.08 & -0.04 \\
\hline & $\begin{array}{l}(0.13 \\
0.56)\end{array}$ & $\begin{array}{l}(-0.11 \\
0.11)\end{array}$ & $\begin{array}{l}(-0.44, \\
-0.09)\end{array}$ & $\begin{array}{l}(-0.17, \\
0.34)\end{array}$ & $\begin{array}{l}(-0.30, \\
0.14)\end{array}$ & $\begin{array}{l}(-0.28, \\
0.21)\end{array}$ & $\begin{array}{l}(-0.34, \\
0.19)\end{array}$ & $\begin{array}{l}(-0.14, \\
0.07)\end{array}$ \\
\hline \multirow{2}{*}{$\begin{array}{l}\text { Christian } \\
\text { religion (ref } \\
\text { = Other } \\
\text { religion) }\end{array}$} & 0.05 & -0.02 & 0.04 & -0.13 & -0.02 & 0.37 & 0.07 & 0.01 \\
\hline & $\begin{array}{l}(-0.16 \\
0.27)\end{array}$ & $\begin{array}{l}(-0.13, \\
0.09)\end{array}$ & $\begin{array}{l}(-0.13 \\
0.21)\end{array}$ & $\begin{array}{l}(-0.39, \\
0.12)\end{array}$ & $\begin{array}{l}(-0.24, \\
0.20)\end{array}$ & $\begin{array}{l}(0.14 \\
0.60)\end{array}$ & $\begin{array}{l}(-0.18, \\
0.32)\end{array}$ & $\begin{array}{l}(-0.10, \\
0.11)\end{array}$ \\
\hline \multicolumn{9}{|l|}{$\begin{array}{l}\text { District (ref = } \\
\text { Caia) }\end{array}$} \\
\hline \multirow[t]{2}{*}{ Chemba } & -0.05 & 0.03 & -0.29 & 0.36 & -0.16 & -0.60 & -0.10 & -0.11 \\
\hline & $\begin{array}{l}(-0.49 \\
0.39)\end{array}$ & $\begin{array}{l}(-0.19, \\
0.25)\end{array}$ & $\begin{array}{l}(-0.63, \\
0.06)\end{array}$ & $\begin{array}{l}(-0.16, \\
0.87)\end{array}$ & $\begin{array}{l}(-0.57, \\
0.25)\end{array}$ & $\begin{array}{l}(-0.97 \\
-0.22)^{\prime}\end{array}$ & $\begin{array}{l}(-0.51 \\
0.32)\end{array}$ & $\begin{array}{l}(-0.31, \\
0.09)^{\prime}\end{array}$ \\
\hline \multirow[t]{2}{*}{ Cheringoma } & -0.11 & 0.11 & -0.28 & -0.10 & -0.16 & -0.43 & -0.36 & -0.15 \\
\hline & $\begin{array}{l}(-0.52 \\
0.29)\end{array}$ & $\begin{array}{l}(-0.09 \\
0.31)\end{array}$ & $\begin{array}{l}(-0.59 \\
0.04)\end{array}$ & $\begin{array}{l}(-0.57 \\
0.37)\end{array}$ & $\begin{array}{l}(-0.54 \\
0.21)\end{array}$ & $\begin{array}{l}(-0.78, \\
-0.07)\end{array}$ & $\begin{array}{l}(-0.76, \\
0.03)\end{array}$ & $\begin{array}{l}(-0.34, \\
0.04)\end{array}$ \\
\hline \multirow[t]{2}{*}{ Chibabava } & -0.39 & 0.11 & -0.23 & 0.20 & 0.04 & -0.49 & -0.24 & -0.09 \\
\hline & $\begin{array}{l}(-0.82 \\
0.03)\end{array}$ & $\begin{array}{l}(-0.10 \\
0.33)\end{array}$ & $\begin{array}{l}(-0.56, \\
0.10)\end{array}$ & $\begin{array}{l}(-0.29 \\
0.69)\end{array}$ & $\begin{array}{l}(-0.36 \\
0.43)\end{array}$ & $\begin{array}{l}(-0.85 \\
-0.13)\end{array}$ & $\begin{array}{l}(-0.64, \\
0.16)\end{array}$ & $\begin{array}{l}(-0.28, \\
0.11)\end{array}$ \\
\hline \multirow[t]{2}{*}{ Gorongosa } & -0.29 & 0.12 & -0.06 & -0.06 & -0.32 & -0.51 & 0.17 & -0.12 \\
\hline & $\begin{array}{l}(-0.80 \\
0.22)\end{array}$ & $\begin{array}{l}(-0.13, \\
0.38)\end{array}$ & $\begin{array}{l}(-0.46 \\
0.33)\end{array}$ & $\begin{array}{l}(-0.64, \\
0.53)\end{array}$ & $\begin{array}{l}(-0.79 \\
0.15)\end{array}$ & $\begin{array}{l}(-0.94, \\
-0.07)\end{array}$ & $\begin{array}{l}(-0.31 \\
0.65)\end{array}$ & $\begin{array}{l}(-0.36, \\
0.11)\end{array}$ \\
\hline \multirow[t]{2}{*}{ Machanga } & -0.34 & 0.11 & -0.12 & 0.48 & 0.34 & -0.25 & -0.01 & 0.07 \\
\hline & $\begin{array}{l}(-0.79 \\
0.11)\end{array}$ & $\begin{array}{l}(-0.12, \\
0.33)\end{array}$ & $\begin{array}{l}(-0.47 \\
0.23)\end{array}$ & $\begin{array}{l}(-0.04, \\
1.01)\end{array}$ & $\begin{array}{l}(-0.08, \\
0.76)\end{array}$ & $\begin{array}{l}(-0.63, \\
0.13)\end{array}$ & $\begin{array}{l}(-0.44 \\
0.41)\end{array}$ & $\begin{array}{l}(-0.13, \\
0.28)\end{array}$ \\
\hline \multirow[t]{2}{*}{ Maringue } & -0.42 & 0.22 & 0.30 & 0.43 & 0.71 & -0.51 & 0.39 & 0.27 \\
\hline & $\begin{array}{l}(-0.96 \\
0.12)\end{array}$ & $\begin{array}{l}(-0.05, \\
0.49)\end{array}$ & $\begin{array}{l}(-0.12, \\
0.72)\end{array}$ & $\begin{array}{l}(-0.20, \\
1.05)\end{array}$ & $\begin{array}{l}(0.21, \\
1.21)^{\prime}\end{array}$ & $\begin{array}{l}(-0.98 \\
-0.04)\end{array}$ & $\begin{array}{l}(-0.12 \\
0.91)\end{array}$ & $\begin{array}{l}(0.03, \\
0.52)\end{array}$ \\
\hline \multirow[t]{2}{*}{ Marromeu } & -0.42 & -0.02 & -0.11 & 0.20 & -0.03 & -0.56 & -0.20 & -0.11 \\
\hline & $\begin{array}{l}(-0.87 \\
0.02)\end{array}$ & $\begin{array}{l}(-0.24, \\
0.21)\end{array}$ & $\begin{array}{l}(-0.45 \\
0.24)\end{array}$ & $\begin{array}{l}(-0.32, \\
0.71)\end{array}$ & $\begin{array}{l}(-0.45 \\
0.38)\end{array}$ & $\begin{array}{l}(-0.94 \\
-0.18)\end{array}$ & $\begin{array}{l}(-0.62, \\
0.22)\end{array}$ & $\begin{array}{l}(-0.32, \\
0.09)\end{array}$ \\
\hline
\end{tabular}

\section{Discussion}

The purpose of this study was to assess the CHWs knowledge, attitudes, and practices towards epilepsy across nine districts in Sofala province, Mozambique. CHW knowledge of medical treatment and epilepsy safety/risks were adequate. However, information on the causes of epilepsy, stigmatizing attitudes, cultural treatment, and some aspects of epileptic crisis response were low. Knowledge regarding the causes of epilepsy was limited 
among $\mathrm{CHWs}$ relative to the other subscales. $\mathrm{CHWs}$ did not believe that epilepsy could be inherited or related to childhood injury, but correctly identified head injury, malaria/meningitis/fever, and brain injury as risk factors and this is against the false perception in an unpublished study done in the south of Mozambique, where the majority of population related the epilepsy cause to "bad spirits"(27). In our study CHWs displayed moderate to high levels of knowledge regarding medical intervention, epilepsy safety/risks, and some aspects of practices during crisis of epilepsy. Maintaining and strengthening these domains of knowledge regarding medical, safety/risks perceptions, and some aspects of practices during crisis for epilepsy can allow CHWs to facilitate linkages between the community and PHC. They can do this by highlighting the availability of conventional treatment of different epilepsy designations in the local health network and awareness of some dangerous practices during crisis. There is a general understanding that cultural context is often complicated by different terms used to designate epilepsy, generally associated with different causes ${ }^{(28)}$ and may impact medical treatment negatively, when considering some of these different designations of epilepsy as treatable in traditional healers or church instead of going to hospital. An unpublished study done in the south of Mozambique emphasized that the various designations of epilepsy such as "moon disease" and "spirit disease" can support beliefs and myths that traditional healers are the best individuals to treat epilepsy(29).

Some CHWs have adequate knowledge about some of the inaccuracies of the cultural treatments of epilepsy evidenced by the non-acceptance of dangerous practices such as putting a stick in the mouth during seizures a significant proportion of CHWs still believed that when local names for epilepsy were used such as Dzumba or Nzwiti, these could not be treated. The differences of opinions related to treatments for epilepsy by the use of local versus non-local terms demonstrates the danger of non-dissemination of the local terms that could be a barrier for $\mathrm{CHW}$ performance in linking $\mathrm{PWE}$ in the community to $\mathrm{PHC}^{(28)}$. Other worrying perceptions were that many $\mathrm{CHWs}$ believed that individual's knees should be stretched during a seizure or that people should be held during seizures, which are very dangerous practices for PWE and contrary to standardized protocols about proper conduct during epileptic crises. Understanding the cultural beliefs gives an insight into how people cope with epilepsy ${ }^{(30,31)}$. In the absence of this knowledge, misunderstanding between CHWs, PWE and health professionals ${ }^{(32)}$ may occur resulting in poor adherence to antiepileptics medicines.

This study also revealed negative and stigmatizing attitudes held by a notable proportion of CHWs toward PWE. Many CHWs felt that PWE shouldn't/can't have a normal life and are a burden to their family. While most CHWs did not report these attitudes, other studies have found that PWE have often been marginalized in their societies with less opportunities for education, social relationships, employment and marriage ${ }^{(28,33)}$ as epilepsy is seen by the public as a highly contagious and shameful condition ${ }^{(34)}$. In this study we found that there was some variability in knowledge about epilepsy by demographic factors and district, which may be explained in part by the different cultural contexts of each district.

It is noteworthy that the current CHWs training package, in Mozambique, does not include epilepsy, which may be one obstacle to acquisition of positive knowledge, attitudes and practices towards epilepsy, reinforcing the existing negative attitudes towards PWE. Given that most individuals trained as CHWs have strong cultural influence in the communities where they are inserted ${ }^{(18)}$, they could be catalysts to improve CHWs "bridging" of PWE to PHC. The strength of CHWs being "integrated" into the community allow them to relate well to the local community but can be harmful if effective practices are not adequately instilled during training. 
These findings must be interpreted considering several limitations. First, we used a Portuguese instrument that at some point may not have facilitated the comprehension of the instrument in its entirety by CHWs. Second, although adapted, this instrument had not been previously validated for the context of Mozambique. To account for this limitation, we evaluated the internal consistency and internal construct validity of this measure prior to evaluating the levels and correlates of knowledge, attitudes, and practices related to epilepsy. The low to moderate internal consistency may be due in part the subscales contained poorly correlated items, demonstrated by the low item rest correlation for items within the three sub-scales practices during crisis, causes of epilepsy, medical treatment, meaning that may be less informative or not specific to the construct in question. Third, this was an exploratory study with 135 community health workers. Given the small sample size and the descriptive, exploratory nature of the study, we did not correct for multiple comparisons.

This study also possessed several strengths. First, to our knowledge this is one of the few published studies to evaluate the knowledge, attitudes, and practices towards epilepsy among CHWs in low-resource settings. Given the high prevalence and burden of disease attributable to epilepsy in low-resource settings and the critical role of CHWs in increasing access to health services for vulnerable populations, particularly those with stigmatized health conditions, identifying knowledge gaps and clinical strengths is imperative. This study also provided preliminary information on the psychometric properties of a Portuguese QKAP-EPI in Mozambique. Based on the information from this first phase of the study, the CHWs training package for CHWs will be developed, adapted, implemented and assessed the effect training of CHWs.

\section{Conclusion}

In general, the $\mathrm{CHWs}$ presented a moderate level of knowledge about epilepsy, evidenced by the fact that all subscale scores ranged from 1 to values close to the maximum score of 2 . Heterogeneity of this knowledge across different districts of Sofala province was present, particularly when using different local names for epilepsy (Dzumba and Nzwiti). This study highlights the need to attend to local cultural believes, local terms and practices towards epilepsy when designing programs of epilepsy prevention and care, and the dissemination of different local terms of epilepsy in different districts. A CHWs training program is required in order to enhance the level of knowledge, attitudes and practices about epilepsy and to facilitate the provision of adequate care and treatment of community members with epilepsy. Furthermore, adequate training of $\mathrm{CHWs}$ will also improve their bridging role to PHC by strengthening referral and contra-referral of PWE living in communities served by CHWs.

\section{Abbreviations}

\section{CHWs}

Community Health Workers. Cl:Confidence Interval. GBD:Global Burden Disorder. CFI:Comparative Fit Index. CMDs:Common Mental Disorders. DOT:Direct Observation Treatment. LMICs:Low - and Middle - Income Countries. mhGap:Mental Health Gap Action Plan. MISAU:Ministry of Health, Mozambique. MZ:Mozambique. PWE:People with Epilepsy. NCDs:Non-Communicable Disorders. PHC:Primary Health Care. QKAP_EPI:Questionnaire of Knowledge, Attitude, Practices of Epilepsy. WHO:World Health Organization. YLD:Years Lived with Disability. TB:Tuberculosis. RMSEA:Root Mean Square Error of Approximation. TLI:Tucker Lewis Index. SRMR:Standardized Root Mean Residual. 


\section{Declarations}

\section{Statement:}

we confirm that we have read the Journal's position on issues involved in ethical publication and affirm that this report is consistent with those guidelines.

\section{Ethics Approval and Consent to Participate:}

this study was approved by the institutional review boards of Eduardo Mondlane University (Medical School) \& Maputo Central Hospital Ethical Review Committee under registration CIBS FM\&HCM/74/2016.

\section{Consent to Publish:}

not applicable.

\section{Availability of Data and Materials:}

the data are available under reasonable request addressed to Vasco Cumbe (vcumbe@gmail.com).

\section{Competing Interest:}

The authors have no conflicts of interest.

\section{Funding:}

This work was supported by Project $41-8^{\text {th }}$ Call from the National Fund of Investigation in Mozambique (FNI), 2017. The content of this paper is solely the responsibility of the authors and does not represent the official views of the National Fund of Investigation of Mozambique (FNI). The other support was from D43TW009675, a NIMH - Fogarty grant for the "PALOP Mental Health Implementation Research Training", a joint project between the New York State Psychiatric Institute - Columbia University Department of Psychiatry, Eduardo Mondlane University Medical School, Ministry of Health of Mozambique and Federal University of Sao Paulo, Psychiatry Department.

\section{Contributions:}

VFJC, MS, MLCG, JDJM, MO, MW conceived the idea, led the organization of the study, the tools adaptation process, and data collection. VFJC supervised data collection in health facilities with input from AMTF, HF, DM, MLCG. VFJC, AMTF, HF led the data entry and clean-up in the database. All provided detailed input to the tool's adaptation process. All author contributed to writing the paper and provided some inputs. VFJC, MCG led the analyses. VFJC wrote the first version of the paper with support from MS, CD, JDJM, MO, MW and all other authors.

\section{Acknowledgments:}

The authors would like to thank the following health professionals of Sofala Provincial Health Directorate for their support in data collection process (A. Afonso, L. Mortal, M. R. Alficha, G. Fopence, C. Murrumula, S. Machole, J. dos Santos, J. Mário, E. Xerinda, P. Abílio, R. Carimo, F. Satar, I. Machale, S. Aleixo, J. Matchesso, H. 
Fumo, A. Fumo, G. Madeira, and to the Head of Sofala Provincial Health Directorate (Chico Sande, Priscilla Filimone, Fino Massalambane) for their support in some logistics. Special thanks to Prof Doctor Mohsin Sidat (Dean of Faculty of Medicine, Eduardo Mondlane University) and Maria Lídia Chauque Gouveia (Head of Department of Mental Health, MISAU). Extended thanks to Bradley Wagenaar for his support in the critical view of the manuscript.

\section{References}

1. World Health Organization. EPILEPSY IN THE WHO AFRICAN REGION: Bridging the Gap. The Global Campaign Against Epilepsy “ Out of the Shadows”. Geneva, Switzerland. [Internet]. 2004.

2. de Boer HM, Moshé SL, Korey SR, Purpura DP. ILAE/IBE/WHO Global Campaign Against Epilepsy. Curr Opin Neurol [Internet]. 2013 Apr;26(2):219-25.

3. de Boer HM, Mula M, Sander JW. The global burden and stigma of epilepsy. Epilepsy Behav [Internet]. 2008 May;12(4):540-6.

4. Institute for Health Metrics and Evaluation (IHME). GBD Compare Data Visualization: Mozambique. Seattle: University of Washington; 2013.

5. Wagenaar BH, Cumbe V, Raunig-Berhó M, Rao D, Napúa M, Hughes JP, et al. Health facility determinants and trends of ICD-10 outpatient psychiatric consultations across Sofala, Mozambique: Time-series analyses from 2012 to 2014. BMC Psychiatry. 2015;15(1).

6. Wagenaar BH, Cumbe V, Raunig-Berhó M, Rao D, Kohrt BA, Stergachis A, et al. Outpatient Mental Health Services in Mozambique: Use and Treatments. Psychiatr Serv. 2016;67(6):588-90.

7. Ministério de Saúde. Departamento de Saúde. Relatório Anual de Saúde Mental (2014) em Moçambique.

8. World Health Organization. Epilepsy [Internet]

World Health Organization. Epilepsy [Internet]. Geneva S. 2019. Available from: https://www.who.int/newsroom/fact-sheets/detail/epilepsy.

9. World Health Organization. Epilepsy Management at Primary Health Level in rural China: WHO/ILAE/IBE a Global Campaign Against Epilepsy. Demostration Project. WHO China Rep [Internet]. 2009;1-32.

10. Baskind R, Birbeck G. Epilepsy Care in Zambia: A Study of Traditional Healers. Epilepsia [Internet]. 2005 Jul;46(7):1121-6.

11. Organización Mundial de la Salud. Trastornos Neurológicos: desafíos para la salud pública [Internet]. 2006.

12. Patterson V, Samant S, Singh MB, Jain P, Agavane V, Jain Y. Diagnosis of epileptic seizures by community health workers using a mobile app: A comparison with physicians and a neurologist. Seizure [Internet]. 2018 Feb;55:4-8.

13. Santos PF, Wainberg ML, Caldas-de-Almeida JM, Saraceno B, Mari J de. J. Overview of the mental health system in Mozambique: Addressing the treatment gap with a task-shifting strategy in primary care. Int $\mathrm{J}$ Ment Health Syst. 2016;10(1):1-9.

14. Patel V, Weiss H, Chowdhary N, Naik S, Pednekar S, Chatterjee S, et al. The effectiveness of a lay health worker led intervention for depressive and anxiety disorders in primary care: the MANAS cluster randomized trial in Goa, India. Lancet. 2010;376(9758):2086-95. 
15. Chomba EN, Haworth A, Atadzhanov M, Mbewe E, Birbeck GL. Zambian health care workers' knowledge, attitudes, beliefs, and practices regarding epilepsy. Epilepsy Behav [Internet]. 2007 Feb;10(1):111-9.

16. Ezeala-Adikaibe BA, Achor JU, Nwabueze AC, Agomoh AO, Chikani M, Ekenze OS, et al. Knowledge, attitude and practice of epilepsy among community residents in Enugu, South East Nigeria. Seizure. 2014;23(10):882-8.

17. Dolo H, Mandro M, Wonya'Rossi D, Ngave F, Fraeyman J, Siewe JN, et al. Community perceptions of epilepsy and its treatment in an onchocerciasis endemic region in Ituri, Democratic Republic of Congo. Infect Dis Poverty [Internet]. 2018 Dec;4(1):115. 7(.

18. Giuliano L, Cicero CE, Padilla S, Camargo M, Sofia V, Zappia M, et al. Knowledge and attitudes towards epilepsy among nonmedical health workers in rural Bolivia: Results after a long-term activity in the Chaco region. Epilepsy Behav [Internet]. 2018 Aug;85:58-63.

19. Musyimi CW, Mutiso VN, Ndetei DM, Unanue I, Desai D, Patel SG, et al. Mental health treatment in Kenya: Task-sharing challenges and opportunities among informal health providers. Int J Ment Health Syst. 2017;11(1):1-10.

20. Ministério de Saúde. Direcção Nacional de Saúde Pública. Programa de Revitalização dos Agentes Polivalentes Elementares de Saúde - APEs. MISAU, Direcção Nacional de Saúde Pública. 2010.

21. CUMBE VFJ, Muanido AG, Manaca MN, Fumo H, Chiruca P, Hicks L, et al. Validity and Item Response Theory Properties of the Patient Health Questionnaire-9 for Primary Care Depression Screening in Mozambique (PHQ-9- MZ) CURRENT STATUS: UNDER REVIEW. 2019;1-36.

22. Santos PF dos. 25 Anos de Saúde Mental em Moçambique (1984-2009). Rev Psique. $2011 ; 1$.

23. Instituto Nacional de Estatística (INE). Instituto Nacional de Estatística. Anuário da Província de Sofala, 2017 [Internet]. 2017.

24. Direcção Provincial de Saúde de Sofala. Departamento de Saúde Pública. Relatório Anual de Saúde Mental. 2017. Moçambique, Beira. 2018.

25. Mbuba CK, Abubakar A, Hartley S, Odermatt P, Newton CR, Carter JA. Development and validation of the Kilifi Epilepsy Beliefs and Attitude Scale. Epilepsy Behav. 2012;24(4):480-7.

26. Nguyen TH, Han H-R, Kim MT, Chan KS. An Introduction to Item Response Theory for Patient-Reported Outcome Measurement. Patient - Patient-Centered Outcomes Res [Internet]. 2014 Mar 9;7(1):23-35.

27. Nhancale P. Convulsões, Medo e Estigma: Epilepsia, ejile-jile, Nhoka yi Kulo no Bairro Central “C”, Maputo. Dissertação de Licenciatura em Antropologia, Faculdade de Letras e Ciências Sociais. Mozambique, Maputo A [Internet]. Universidade Eduardo Mondlane, Faculdade de Letras e Ciências Sociais; 2015.

28. Sharkawy G, El, Newton C, Hartley S. Attitudes and practices of families and health care personnel toward children with epilepsy in Kilifi, Kenya. Epilepsy Behav. 2006;8(1):201-12.

29. SOBRE COMPORTAMENTOS, ATITUDES E PRÁTICAS SOBRE A EPILEPSIA NOS DISTRITOS DE CHIBUTO E CHÓKWÈ

Langa AP, Gouveia ML, Nhantumbo B, Andrassone P, Nhabinde A, Wate J. RELATÓRIO DO ESTUDO. SOBRE COMPORTAMENTOS, ATITUDES E PRÁTICAS SOBRE A EPILEPSIA, NOS DISTRITOS DE CHIBUTO E CHÓKWÈ, PROVÍNCIA DE GAZA [Internet]. Maputo; 2012.

30. Andermann LF. Epilepsy in Our World: An Ethnographic View. Epilepsy Behav. 2000;1(3):169-75. 
31. Desai P, Padma MV, Jain S, Maheshwari MC. Knowledge, attitudes and practice of epilepsy: Experience at a comprehensive rural health services project. Seizure. 1998;7(2):133-8.

32. Martin AR. Exploring Patient Beliefs: Steps to Enhancing Physician-Patient Interaction. Arch Intern Med. 1983;143(9):1773-5.

33. Giel R. The Epileptic Outcast. East Afr Med J. 1968;45(1):27-31.

34. Kabir M, lliyasu Z, Abubakar IS, Kabir ZS, Farinyaro AU. KNOWLEDGE, ATTITUDE AND BELIEFS ABOUT EPILEPSY AMONG ADULTS IN A NORTHERN NIGERIAN URBAN. Ann Afr Med [Internet]. 2005;4(3):107-12.

35. Direcção Provincial de Saúde de Sofala. Departamento Provincial de Planificação e Cooperação: Projecção da População 2017. Beira: Moçambique; 2018.

\section{Figures}
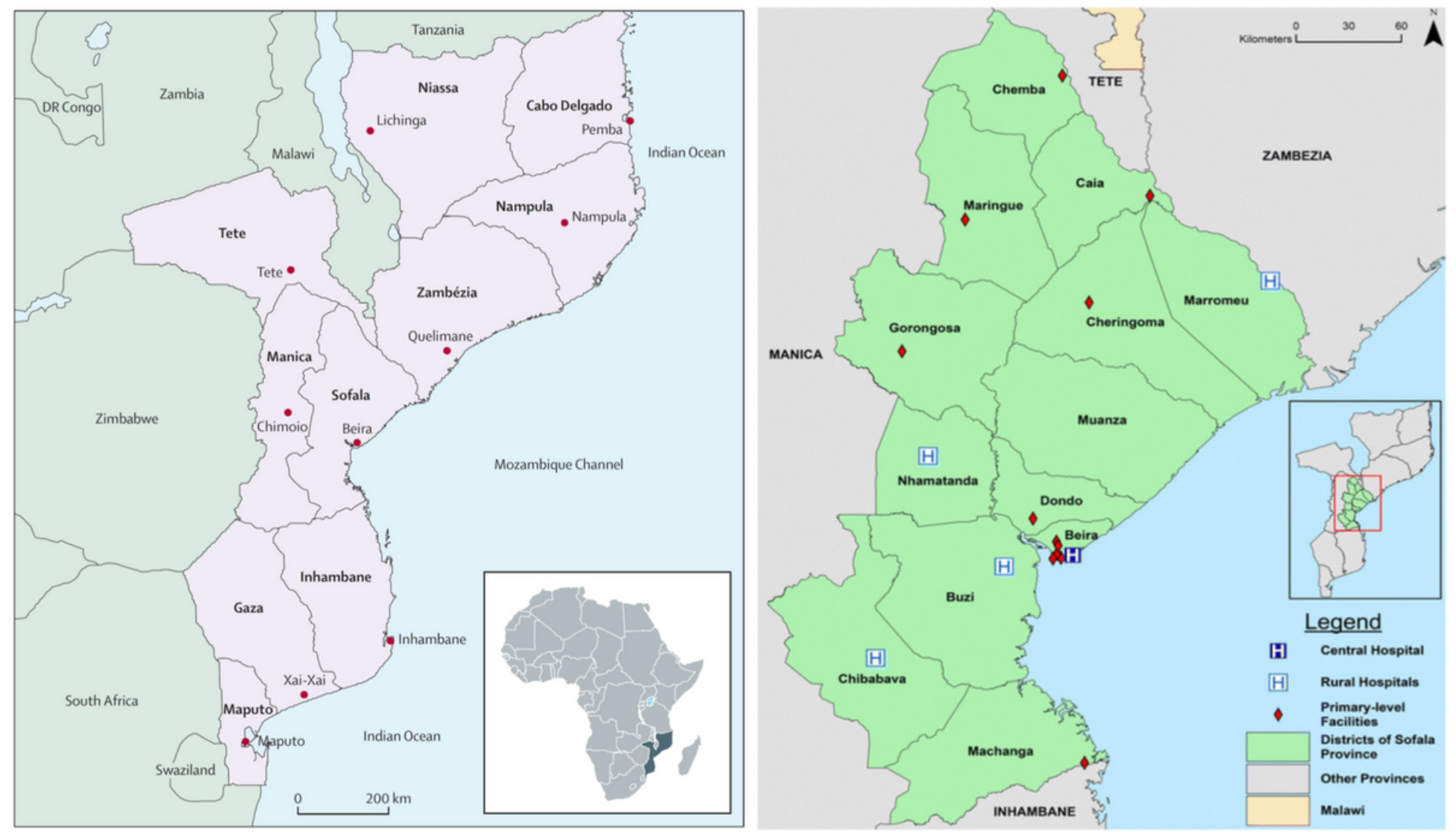

Figure 1

\section{Supplementary Files}

This is a list of supplementary files associated with this preprint. Click to download.

- supplement4.pdf 